\title{
ЛІНГВОПОЕТИКА ЯК НАУКОВИЙ ДОСВІД: ПИТАННЯ МЕТОДОЛОГІЇ І МЕТОДІВ ЛІНГВІСТИЧНОГО АНАЛІЗУ ХУДОЖНЬОЇ МОВИ
}

У статті прокоментовано стан сучасних наукових досліджень з тінгвопоетики в аспекті використаних науковием теоретико-методологійних засад (парадигм) і задіяних у процесі аналізу художньої мови методів. Наголошено на інтегральному характерові сучасної лінгвопоетики як наукового дискурсу, методологійною опорою якого є декілька парадигм, зокрема актуальних - прагматична, когнітивно-дискурсивна, синергійна. Здійснено вибірку методів, найчастіше застосованих науковиями в праиях з лінгвопоетики, проаналізовано особливості й продуктивність їх дослідницьких механізмів.

Ключові слова: лінгвопоетика, художня мова, методологія, парадигма, метод.

Malenko O. Linguistic Poetics as a Scientific Experience: Questions of Methodology and Methods of Linguistic Analysis of Literary Language. The state of modern scientific research in the language of literary texts is commented in the article. The problem of studying and describing literary language is of interest to such a scientific field as linguistic poetics. The author focuses on the methodology and methods of linguistic analysis of literary language. Literary language is understood as a specific form of figurative reflection of life, which appears in the aesthetic evolution against the background of the historical development of the national literary language. The aim of the article is to determine the paradigms of research, which are the methodological basis of them, and comment on methods that are frequent in works on linguistic poetics. The relevance of the article provides general attention of scientists to the problems of methodology and methods of linguistic analysis. Many linguists are concerned that young scholars do not always clearly understand the mechanism of action of selected methods and therefore incorrectly apply them in their own studies. The author of the article emphasizes the integral nature of modern linguistic poetics, which is based on several relevant paradigms: pragmatic, cognitive-discursive, synergistic. Moreover, the taxonomic paradigm is productive, in the dimension of which scientists study and describe the structural levels of literary language as a system. Scientific study and description of the language of a literary text is most often carried out using the following methods: definition analysis, component analysis, structural-semantic analysis, typological analysis, contextual analysis, distributive analysis. The process of research activities is also undertaken with the help of a descriptive method. Interpretive methods are very important, they realize the ability of the scientist to comprehend the object of study in the context 
of cultural and historical time and space, interpret the essence of a certain linguistic phenomenon. The following topical areas are integrated into the context of modern linguistic poetics: linguoconceptology, ethnolinguistics, linguocultural studies, communicative linguistics etc.

Key words: linguistic poetics, literary language, methodology, paradigm, method.

\section{Вступ}

Лінгвопоетика як галузь мовознавчої науки має певну методологійну специфіку, адже інтегрує знання декількох гуманітарних сфер: лінгвістики, літературознавства, філософії, естетики, культурології, психології, що позначається і на використанні відповідних світоглядно-теоретичних засад, дослідницького інструментарію та задіяних методів наукового аналізу. У загальному філологічному дискурсі лінгвопоетику визначають як науку «про взаємодію формальної і змістової будови художнього тексту, про роль мовних елементів у досягненні естетичного ефекту, про тенденції розвитку мови художніх творів у зв'язку зі стильовими напрямами в літературі» (Єрмоленко, 2001: 85). Ця дефініція відмежовує лінгвопоетику від лінгвостилістики науки «про стилі мови, різновиди, форми мовлення, що визначені умовами, ситуацією, метою спілкування і розрізняються відповідними мовними засобами та їхнім функціональним навантаженням» (Там само). Тобто відмінності між цими галузями полягають у диференціації предметної сфери: для лінгвопоетики предметом вивчення й опису є мова художніх творів, для лінгвостилістики - стилі мови, форми мовлення, задіяні в тій чи тій комунікативній ситуації або дискурсивній практиці (детальніше про становлення і розвиток української лінгвопоетики див: Маленко, 2010: 19-45).

Про особливості мови художнього твору писав свого часу Олександр Потебня, який заклав підвалини наукового осмислення художньої (поетичної) мови як художньо-естетичного феномену, сформулював відому й актуальну до сьогодні теорію словесності. Традиційно художню мову розуміють як специфічну форму образного відображення буття в її естетичній еволюції (динаміці) на тлі історичного розвитку національної літературної мови. Художня мова «конденсує, згущує звукові ознаки національної мови, вияскравлює дію іï фонетичних законів, використовує семантичну глибину слів, особливості граматичної будови. Кожний із мовних рівнів, 
що виокремлюються з метою наукового вивчення мови, насправді постає в неподільному сприйманні цілісного мовного організму» (Єрмоленко, 1999: 10).

Важливим щодо ідентифікації лінгвопоетики як досвіду наукового вивчення художньої мови є уточнення стратегічної дослідницької мети: це насамперед виявлення й опис мовних засобів, за допомогою яких автор (письменник) відповідно до власних намірів (інтенцій) організовує формально-змістову площину художнього тексту, досягає естетичного або прагматичного ефекту, утілює й концептуалізує свої буттєві або художні цінності, використовуючи властиві його ідіостилю тропеїстичні засоби. Результати досліджень з лінгвопоетики, на думку їі фундатора В. Виноградова, забезпечують глибше розуміння проблем еволюції художньої мови як багаторівневого стилістичного різновиду загальнонародної, дають повніші уявлення про формування й загальний розвиток естетичного мовомислення (універсального й національного) та загалом словесно-художнього мистецтва в надрах кожної із культур (Виноградов, 1959: 170-171). Цьому підтвердження - праці 3 лінгвопоетики відомих українських мовознавців С. Бибик, Г. Вокальчук, Н. Данилюк, С. Єрмоленко, В. Калашника, Л. Лисиченко, Л. Мацько, А. Мойсієнка, О. Тєлєжкіної, О. Тищенко, О. Ставицької, В. Чабаненка, Л. Українець та багатьох інших (прим.: у статті згадуємо насамперед авторів монографічних видань, у яких представлені узагальнені результати теоретико-практичного досвіду вивчення художньої мови окремого автора чи дискурсу). Час і наукові тенденції доби помітно оновили дослідницький контент мовознавства в його різних напрямах, що органічно інтегруються в сучасні студії з вивчення художньої мови відповідно до обраної наукової методології, парадигми, мети, об’єкта й предмета вивчення.

Інтегральний характер лінгвопоетики потребує релевантної методологіі і співвідносних із нею методів, щоб науково переконливо реалізувати механізм (алгоритм) аналізу обраного предмета вивчення й отримати очікувані результати. Обсервуючи роботи з лінгвопоетики, особливо молодих науковців, спостерігаємо певну невизначеність і нечіткість у розумінні теоретико-методологійних засад та вибору методів, продуктивних для розв'язання поставлених завдань щодо опису художньої мови в їі різних парадигмах. Ця проблема торкається не лише досліджень художньої мови; сучасні науковці (Ф. Бацевич, 
В. Глущенко, О. Лещак, О. Селіванова та ін.) активно обговорюють загальну тенденцію невизначеності й подекуди некоректності щодо вибору методологій і методів лінгвістичних шукань. Така ситуація спричинена, на думку мовознавця О. Лещака, нечітким розумінням методологійних основ лінгвістичних досліджень, недостатнім усвідомленням сутності об’єкта вивчення та кінцевої мети його опису, подекуди механічним, а тому непродуктивним застосуванням тих чи тих методів (Лещак, 2010: 112).

Тож метою поданої розвідки є прагнення з'ясувати таке: з опорою на які дослідницькі методології і за допомогою яких методів лінгвістичного аналізу слід вивчати й описувати мовні засоби, що мають художньо орієнтовану семантику й прагматику відповідно до намірів та комунікативних цілей автора; які дослідницькі стратегії й тактики роботи з художньомовним матеріалом забезпечать більш переконливі результати з огляду на складність, неодновимірність, феноменальність і самого процесу художньої творчості, і іï результату - художнього тексту, і його матеріалу - національної мови в іï стилістичних та дискурсивних ресурсах.

\section{Методи дослідження}

Оскільки за жанром презентована стаття має аналітично-оглядовий характер, то продуктивними для цієї розвідки є загальнонаукові методи індукції і дедукції, що скеровують думку дослідника від часткового до загального й від загального до конкретного; метод моделювання; прийом спостереження над текстовим матеріалом, його аналіз і синтез у розгортанні відповідних умовиводів.

\section{Виклад основного матеріалу}

Для занурення в проблеми методології і методів лінгвопоетичних досліджень варто визначитися з дефініціями цих понять, зрозуміти їхню призначеність, відмінність і пошукову спрямованість. Методологію прийнято розглядати поліаспектно: як загальнобілософську (світоглядну) категорію і як дослідницьку. У філософському вимірі методологія постає як «галузь теоретичних знань і уявлень про сутність, форми, закони, порядок та умови застосування підходів, способів, процедур у процесі наукового пізнання та практичної діяльності людини» (Філософський..., 2002: 374). Відповідно до того, 
як змінювалися філософські погляди на процеси людського пізнання, було сформовано такі глобальні методології: феноменологія, позитивізм, раціоналізм, функціоналізм (Селіванова, 2006: 345). У межах цих загальнофілософських методологій розглядають і мову, прагнучи з'ясувати іï сутність та визначити роль у пізнавальній діяльності людини. Це уможливило загальне світоглядне (онтологійне) розуміння мови й забезпечило ії конкретні, суто лінгвістичні вектори вивчення: концепції граматичного опису мови; опис структурних рівнів мови як системи; заглиблення в когнітивні механізми мовленнєвої діяльності, дослідження функціонального (прагматичного) потенціалу мовних одиниць та явищ.

Методологія в ії теоретико-практичному аспекті вивчення мови це «вчення про принципи дослідницької діяльності в науці про мову»; у прикладному - «система вихідних принципів і спеціальних методів дослідження мови» (Мельничук, 2007: 354-355). Обрана ученим методологія спрямовує лінгвістичне дослідження в потрібне річище, забезпечує йому системність, цілісність, логічність, переконливість, результативність. Методи як конкретні механізми й прийоми аналізу, систематизації, класифікації, опису мовних одиниць чи явищ мають насамперед функційне призначення в дослідженні, адже вони забезпечують переконливість та об’єктивність наукових результатів.

Якщо говорити про загальнофілософську основу досліджень з лінгвопоетики, то нею $є$ методологія функціоналізму, що передбачає опору на функційність мовних одиниць у творенні художнього повідомлення і визначає потенціал мови в моделюванні художньої ситуації, творенні словесних образів, здійсненні художньої інтеракції.

Принципи дослідницької діяльності в мовознавстві корелюють 3 лінгвістичними теоретико-методологійними парадигмами, актуальними для синхронного наукового вивчення й опису мови та мовних явищ. Парадигму, услід за М. Алефіренком, розуміємо як «панівну на кожному етапі історії лінгвістичних учень систему поглядів на мову, яка (система поглядів) і визначає предмет та принципи лінгвістичного дослідження відповідно до культурно-історичного й філософського контексту епохи» (Алефиренко, 2016: 17-21). У сучасному мовознавстві продуктивними є такі парадигми: прагматична (кореляції мова - мовлення - комунікація), когнітивно-дискурсивна (кореляції мова - мислення, мова - структури знань; мова - дискурс), 
синергійна (кореляції мова - синергія; мова - саморганізована система); проте не втрачають актуальності дослідження, здійснені в генетичній (порівняльно-історичний вимір мови) і таксономічній (мова як структура; опис структурних рівнів мови) парадигмах.

У форматі цих теоретико-методологійних засад науковці прагнуть дослідити результати мовної діяльності людини, серед яких суспільно вагомим та культурно значущим є художній текст і ширше - різножанровий художній дискурс у його лінгвокомунікативній репрезентації. 3 огляду на інтеграцію актуальних парадигм майже в усі галузі українського мовознавства (поліпарадигмальність), зокрема й у лінгвопоетику, маємо певну синкретичність методологійних принципів, інструментарію та механізмів наукового вивчення художньої мови, яку зараз розглядають ширше, ніж у поданому вище традиційному розумінні, тобто не лише як специфічну форму образного відтворення дійсності в художньому тексті в ії динаміці.

У вимірі лінгвоконцептології та лінгвокультурології художня мова постає як особлива концептуально-мовна картина світу (колективна (фольклор) або персональна (ідістиль митця), продукт вербальної творчості, зануреної в культурний контекст часу й простору, а предметом вивчення $є$ мовні засоби репрезентації в художньому тексті тих чи тих концептів (онтологійних, культурних, універсальних, індивідуальних та ін.: праці Т. Вільчинської, К. Голобородька, Н. Голікової, Л. Мялковської та ін.). Послідовники когнітивної поетики розуміють художню мову як результат дії складних когнітивних механізмів людської свідомості щодо породження й декодування сенсів (праці О. Воробйової, Л. Кравець, В. Кононенка та ін.), тож їх цікавить питання, як «поетична мова й загалом художні форми, а також сприйняття поетичного i, ширше, художнього тексту регламентуються й визначаються характером концептуалізації, тобто осмислення світу людиною, а також особливостями притаманних ій когнітивних процесів раціональної й емоційної обробки інформації» (Воробйова, 2004: 37). Комунікативна тінгвістика осмислює художню мову як особливий мовний код, задіяний в естетично або прагматично спрямованій комунікації, реалізованій у континуумі «автор - текст - читач» і зумовленій відповідними авторськими інтенціями (праці Ф. Бацевича, В. Корольової, Я. Сазонової та ін.). Дискурсологія вивчає власне текстовий та інтертекстовий ресурс творення художнього дискурсу, 
у вимірі якого художня мова $є$ синтезом прецедентного й власне авторського словесно-образного ресурсу (праці Г. Сюти, О. Маленко та ін.).

Прокоментовані лінгвістичні напрями спираються на антропоцентричний підхід у вивченні мови, світоглядною опорою якого $\epsilon$ людина - суб’єкт й об’єкт мовної діяльності. Певною мірою їм опозиціонує синергійна парадигма, зокрема мовознавча галузь лінгвосинергетика, що ідентифікує художній текст як упорядковану різнорівневу систему, цілісний організм, здатний до формально-змістової самоорганізації й породження складних смислів завдяки особливій мовнорівневій системності, а мову художнього тексту розуміє як художню синергію, самоорганізовану комплексну систему з наявністю відповідних регуляторних механізмів (праці О. Семенець та ін.).

Залежно від наукових намірів та передбачень дослідник обирає об’єкт вивчення й опису (художня мова автора, тексту або дискурсу), предмет (мовні засоби творення художнього або прагматичного ефекту в тексті / дискурсі), відповідну методологійну парадигму, у межах якої буде здійснене дослідження, та релевантні для аналізу й синтезу зібраного мовного матеріалу лінгвістичні методи. Метод за О. Селівановою розуміємо як спосіб організації дослідницької діяльності науковця з метою вивчення наукового об’єкта; у дослідженні цей спосіб реалізується системою відповідних процедур і прийомів (Селіванова, 2006: 329). Тобто кореляція методологія - парадигма - метод має бути логічною, доцільною і послідовною в іï теоретико-практичному вияві, де теорія слугує методологійною опорою, а практика реалізується в доречно дібраних методах. I, як уже було зазначено, саме методи є тим механізмом, що робить дослідження з лінгвопоетики науково переконливим та наближує його результати до певних узагальнень щодо стану, розвитку й функціонування художньої мови (реалізація потенціалу художньої свідомості) на певному конкретноісторичному (культурному) етапі.

Ускладнює шлях до таких результатів та узагальнень міждисциплінарний характер лінгвопоетики, іï лінгвістично-літературознавчий дуалізм, адже художній текст насамперед є продуктом літературної творчості, об’єктивованої мовою. Ця творчість, здійснювана конкретним митцем у конкретному культурно-історичному часі й просторі, зазнає впливу багатьох внутрішніх (психоемоційні 
характеристики автора, його вік, соціальний статус, освітній ценз, ціннісні домінанти) та зовнішніх чинників (суспільно-історична епоха, світоглядні, духовні, художньо-естетичні орієнтири доби та ін.). Мова як матеріал літературної творчості фіксує ці параметри, акумулюючи різноаспектну інформацію в пропонованих автором ідеях, мотивах, образах, сенсах. Тому важливим для науковця завданням $€$ вибір методів, що сприятимуть реалізації комплексної, інтегральної програми дослідження художньої мови.

Серед лінгвістичних методів, що задіяні в дослідженнях художньої мови, маємо такі, що 1) реалізують аналітичну рецепцію мовного матеріалу, і такі, що 2) активізують інтерпретаційний складник дослідницької роботи з художнім текстом.

Огляд наявних монографій, дисертацій, авторефератів і статей 3 лінгвопоетики засвідчив частотне застосування науковцями таких методів першої групи (аналітична рецепція): метод лінгвістичного спостереження - для фіксації в художньому тексті обраного мовного матеріалу та його первинного аналітичного осмислення; метод дебініційного аналізу - для ідентифікації поняттєвого обсягу лексеми - основи словесного образу; метод етимологійного аналізу - для з'ясування генетичної природи мовної одиниці, ії структури та внутрішньої форми, що зумовило формування відповідного словесного образу; метод компонентного аналізу - для дослідження семної структури лексичної одиниці з метою фіксації нових семантичних варіантів слова в контексті та визначення тих ядерних сем, що формують смислове наповнення образної моделі; метод структурно-семантичного аналізу - для структурно-семантичної класифікації мовних одиниць, задіяних у творенні словесного образу чи художньої ситуації; описовий метод - для загального аналізу, систематизації, інвентаризації мовних одиниць, задіяних у лінгвостилістичній організації художнього тексту (цими одиницями можуть бути звуки, слова, речення, фразеологізми, інтертекстеми); функиійний метод - для вивчення прагматичного потенціалу мовних одиниць у реалізації художньої функції в тексті; метод типологійного аналізу (класифікаційний метод) - для типологізації мовних одиниць за відповідними критеріями (генетичними, семантичними, структурними, прагматичними, функціональними та ін.); метод контекстуального аналізу - для визначення й опису місця мовної одиниці в художньому 
контексті; метод стилістичного аналізу - для з'ясування мовно-виражального (стилістичного) потенціалу мовних одиниць у художньому тексті; метод дистрибутивного аналізу - для виявлення функційних ресурсів мовного оточення лексичних одиниць у контексті (творення образних моделей чи художньої ситуації, нашарування додаткових (емотивно-оцінних) конотацій).

Якщо дослідження художньої мови передбачає занурення в когнітивні площини, зокрема у вимір авторської концептуалізації буття в художньому тексті, то задіюють метод лінгвоконцептуального аналізу - для визначення структурно-змістового обсягу (сукупності ментальних смислів) номінантивних одиниць, які стали в тексті вербальними знаками досліджуваних художніх концептів, що функціонують як одиниці ментального й культурного простору. Цей метод надто загальний і комплексний, тож ідеться більшою мірою про методику лінгвоконцептуального аналізу, що охоплює специфічні методи: власне концептуальний аналіз (виявлення й опис змісту художнього образу-концепту); метод фреймового моделювання - для розуміння художнього концепту як структурної моделі-фрейму, опис рівнів фреймової моделі для укомпактнення наявної інформації про художній концепт; інструментарій теорії когнітивної метафори для усвідомлення процесів метафоризації, механізмів формування образного й ціннісного складника концепту в універсальному чи етнокультурному континуумі (Заньковська, 2015: 102). Окрім цього, для опису змістового обсягу художніх концептів долучають загальнолінгвістичні методи дефініційного, компонентного, етимологійного, контекстуального, структурно-семантичного, кількісного аналізу (Там само).

Поки не частотними, але перспективними в україністиці $є$ дослідження художнього тексту як специфічної, художньо орієнтованої комунікації, у вимірі якої художня мова постає каналом трансляції авторських сенсів і джерелом творення рецептивних смислів, а також матеріалом для формування дискурсу всередині самого художнього тексту (контент прагматичної і дискурсивної парадигм). Для реалізації дослідницьких завдань комунікативної лінгвістики, інтегрованої в простір лінгвопоетики, науковці використовують, окрім суто лінгвістичних, такі специфічні методи: дискурсивний аналіз для комплексного опису естетично або прагматично маркованих 
комунікативних ситуацій у художньому тексті з урахуванням внутрішніх і зовнішніх чинників; для опису стратегій та мовних засобів досягнення авторської інтенції; метод прагмалінгвістичного моделювання - для реконструкції моделей і схем текстової комунікації між автором і читачем (автор - читач) або ситуаційної комунікації між суб'єктами художнього наративу (персонаж - персонаж); метод конверсаційного аналізу - для встановлення лінгвокомунікативних механізмів управління свідомістю або поведінкою героїв художнього тексту (мова як засіб маніпуляції).

Усі прокоментовані методи реалізують насамперед аналітичну діяльність дослідника мови художнього тексту, його здатність здійснити логічний аналіз мовного матеріалу, задіяного у творенні художнього тексту, спираючись на наявні алгоритми (методи, прийоми), виконуючи певні операційні дії для обробки цього матеріалу й отримання потрібної інформації. Але вкрай важливими й продуктивними в роботах з лінгвопоетики є інтерпретаційні методи, які скеровані на індивідуальну дослідницьку рефлексію, верифікацію, науково-креативне осмислення художньомовних явищ у їх дискурсивному функціоналі, що забезпечує глибше проникнення в сутність досліджуваного об’єкта. До таких методів належать: інтерпретаційно-текстовий аналіз - для релевантного опису різнорівневих лінгвостилістичних засобів, тропів, фігур, інтертекстем як інструментів створення художнього або прагматичного ефекту в контексті; метод лінгвокультурної інтерпретації, що забезпечує переведення змісту художнього контексту (або концепту) в площини певної культурної традиції з ії семіотичними кодами (загальний чи національний універсум культури).

Продуктивність використання цих інтерпретаційних методів залежить від екстралінгвістичних факторів, пов'язаних насамперед з особистим інтелектуальним, загальнонауковим, культурним досвідом науковця: чим потужніший його світоглядний та знаннєвий потенціал, ширші культурна, літературна й загалом гуманітарна обізнаність, тим глибше й переконливіше буде його власний дослідницький дискурс щодо наукової інтерпретації феномену художньої мови в кожному іiі текстовому вияві. Знання процесів еволюції художнього мовомислення в динаміці естетичних програм, напрямів, течій, 
жанрів, мотивів, образів (тобто іманентних сутностей художнього твору) забезпечить більш панорамні й переконливі результати, уможливить вихід на узагальнення щодо розвитку національної художньої мови на певному культурно-історичному етапі й окреслення ії дискурсивних перспектив.

Звісно, що переваги в такому глибокому дослідницькому опрацюванні художньої мови належать досвідченим науковцям, які не лише доречно й продуктивно використовують методи лінгвістичного аналізу, а й мають потужний потенціал філологічних і ширше - гуманітарних знань; здатні до філософської рецепції художнього тексту, до розуміння його місця і ваги в універсальному та національному культурному просторі. У молодого дослідника така масштабність може бути досягнена формуванням не тільки лінгвістичної, але й загальної філологічної свідомості як гетерогенної фахової картини світу, що сьогодні $є$ актуальною і суголосною часові потребою гуманітарної науки й освіти.

\section{Висновки}

На завершення нашої рефлексії хотілося 6 навести думку Олега Лещака про умови досягнення мовознавцем переконливих результатів у лінгвістичних дослідженнях: «Тільки розуміючи сутність свого об’єкта, він (учений) може зрозуміти, у чому полягає його дослідження, і тільки після цього конкретні пізнавальні завдання, які він ставить перед собою, будуть мати хоч якийсь сенс. I тільки після того, як лінгвіст усвідомить для себе весь спектр методологійних проблем, він зможе підібрати оптимальні методи, співвідносні із цим об’єктом, необхідні й достатні для цього роду досліджень. <...> Тільки як епістемологічно обгрунтовані способи дій щодо обраного об'єкта ці методи можуть стати потужним знаряддям наукових досягнень» (Лещак, 2010: 112). Тож мовознавцеві, що досліджує художню мову, потрібно усвідомлювати іiі як особливе індивідуальне чи колективне лінгвокреативне явище, а тому обирати вектори (парадигми) й механізми (методи) іiі релевантного вивчення й опису, знаходити синхронні епістеми, що дадуть змогу з позицій часу пізнати цей феномен як результат художньо-естетичного освоєння людиною явищ буття. 


\section{ЛІТЕРАТУРА}

1. Алефиренко, Н. Ф. (2016). Современные проблемы науки о языке. Москва: ФЛИНТА: Наука. 2. Виноградов, В. В. (1959). О языке художественной литературы. Москва: Худ. лит. 3. Воробйова, О. П. (2004). Когнітивна поетика в Україні: напрями досліджень. Актуальні проблеми романо-германської філологї в Україні та Болонський процес. Матеріали Міжнар. наук. конф. (с. 37-38). Чернівці: ЧНУ. 4. Єрмоленко, С. Я. (1999). Нариси з української словесності. Київ: Довіра. 5. Єрмоленко, С. Я., Бибик, С. П., \& Тодор, О. Г. (2001). Короткий тлумачний словник лінгвістичних термінів. Київ: Либідь. 6. Заньковська, Г. Д. (2015). Методи дослідження концептів. Наук. вісн. Міжнар. гуманіст. ун-ту. Серія «Філологія», 19 (2), 102-104. 7. Лещак, О. В. (2010). Функционально-прагматическая методология и свойственные ей методы лингвосемиотических исследований. Методи лінгвістичних досліджень. Матеріали Міжнар. наук.-практ. конф. (с. 108-113). Слов'янськ: СДПУ. 8. Маленко, О. О. (2010). Лінгво-естетична інтерпретація буття в украйнській поетичній мовотворчості. Харків: ХІФТ. 9. Мельничук, О. С. (2007). Методологія в мовознавстві. В Українська мова: енциклопедія (3-тє вид.). Київ: Укр. енцикл. 10. Селіванова, О. О. (2006). Сучасна лінгвістика: термінологічна енииклопедія. Полтава: Довкілля-К. 11. Філософсвкий енииклопедичний словник (2002). Київ: Абрис.

\section{REFERENCES}

1. Alefyrenko, N. F. (2016). Sovremennyje problemy nauky o jazyke [Modern problems of language sciens]. Moskva: FLYNTA: Nauka [in Russian]. 2. Vynohradov, V. V. (1959). O jazyke khudozhestvennoj literatury [About the language of fiction]. Moskva: Khud. lit. [in Russian]. 3. Vorobiova, O. P. (2004). Kohnityvna poetyka v Ukraini: napriamy doslidzhen [Cognitive poetics in Ukraine: directions of research]. Aktualni problemy romano-hermanskoi filolohii v Ukraini ta Bolonskyi protses. Materialy Mizhnar. nauk. konf. - Actual problems of Romano-Germanic philology in Ukraine and the Bologna process. Proceedings of the International Scientific Conference (pp. 37-38). Chernivtsi: ChNU [in Ukrainian]. 4. Yermolenko, S. Ia. (1999). Narysy z ukrainskoi slovesnosti [Essays on Ukrainian literature]. Kyiv: Dovira [in Ukrainian]. 5. Yermolenko, S. Ia., Bybyk, S. P., \& Todor, O. H. (2001). Korotkyj tlumachnyj slovnyk linhvistychnykh terminiv [A short glossary of linguistic terms]. Kyiv: Lybid [in Ukrainian]. 6. Zankovska, H. D. (2015). Metody doslidzhennia kontseptiv [Methods of research of concepts]. Nauk. visn. Mizhnar. humanit. un-tu. Seriia «Filolohiia» - Scientific Bulletin of the International Humanities University. Series «Philology», 19 (2), 102-104 [in Ukrainian]. 7. Leshchak, O. V. (2010). Funktsyonalno-pragmatycheskaia metodologija i svoistvennye ej metody lyngvosemyotycheskykh issledovanij [Functionalpragmatic methodology and its inherent methods of linguosemiotic research]. Metody linhvistychnykh doslidzhen. Materialy Mizhnar. nauk.-prakt. konf. - Methods of linguistic research. Proceedings of the International scientific-practical conference (pp. 108-113). Slovyansk: SDPU [in Russian]. 8. Malenko, O. O. (2010). Linhvo-estetychna interpretatsiia buttia $v$ ukrainskij poetychnij movotvorchosti [Linguo-aesthetic interpretation of life in Ukrainian poetic language creation]. Kharkiv: KhIFT [in Ukrainian]. 9. Melnychuk, O. S. (2007). Metodolohiia v movoznavstvi [Methodology in linguistics] In Ukrainska mova: entsyklopediia - Ukrainian language: encyclopedia (3nd ed.). Kyiv: Ukr. entsykl. [in Ukrainian]. 10. Selivanova, O. O. (2006). Suchasna linhvistyka: terminolohichna entsyklopediia [Modern 
linguistics: terminological encyclopedia]. Poltava: Dovkillia-K [in Ukrainian]. 11. Filosofskyj entsyklopedychnyj slovnyk [Philosophical Encyclopedic Dictionary]. (2002). Kyiv: Abris [in Ukrainian].

Маленко Олена Олегівна - доктор філологічних наук, професор, завідувач кафедри українознавства і лінгводидактики, Харківський національний педагогічний університет імені Г. С. Сковороди; вул. Валентинівська, 2, Харків, 61168, Україна.

Tel.: +38 067-938-86-57

E-mail: malenalingva@gmail.com

https://orcid.org/0000-0003-4753-0036

Malenko Olena Olehivna - Doctor of Philological Sciences, Professor, Head of the Department of Ukrainian Studies and Linguistic Didactics, H. S. Skovoroda Kharkiv National Pedagogical University; 2 Valentynivska Str., Kharkiv, 61168, Ukraine.

Надійшла до редакції 23 березня 2021 року

\section{CITATION}

ДСТУ 8302:2015: Маленко О. О. Лінгвопоетика як науковий досвід: питання методології і методів лінгвістичного аналізу художньої мови. Лінгвістичні дослідження: 3б. наук. пр. Харк. нац. пед. ун-ту імені Г. С. Сковороди. Харків, 2021. Вип. 54. Ч. ІІ. C. 99-111. DOI: https://doi.org/10.34142/23127546.2021.54.2.10

APA: Маленко, О. О. (2021). Лінгвопоетика як науковий досвід: питання методології і методів лінгвістичного аналізу художньої мови. Лінгвістичні дослідження, 54 (II), 99-111. DOI: https://doi.org/10.34142/23127546.2021.54.2.10 